\title{
CAMELLIA SPHAMII (THEACEAE, SECT. PIQUETIA), A NEW TAXON OF YELLOW FLOWER FROM LANGBIANG BIOSPHERE RESERVE, VIETNAM
}

\section{Truong Quang Cuonga ${ }^{\mathrm{a}}$, Le Van Huonga ${ }^{\mathrm{a}}$, Le Van Son ${ }^{\mathrm{a}}$, Le Quang Minha Hoang Gia ${ }^{b}$, Luu Hong Truong ${ }^{c}$}

${ }^{a}$ Bidoup Nui Ba National Park, Lam Dong, Vietnam

${ }^{b}$ Lam Dong Power Company, Lam Dong, Vietnam

${ }^{c}$ Southern Institute of Ecology, Vietnam Academy of Science and Technology, Dak Nong, Vietnam

*Corresponding author: Email: quangcuongvqg@gmail.com

\section{Article history}

Received: July $10^{\text {th }}, 2021$

Received in revised form: December $20^{\text {th }}, 2021 \mid$ Accepted: December $30^{\text {th }}, 2021$

Available online: January $28^{\text {th }}, 2022$

\begin{abstract}
Camellia sphamii is described and illustrated as a new species of section Piquetia from Hamasin village, D'ran town, Don Duong district, Lam Dong province, Vietnam. C. sphamii is similar to C. proensis (Quach, Luong et al., 2021) but differs from it in several morphological features: mature leaves cordate at base, young leaves purple; pericarp 7-8 mm thick with dense hair on the outer surface, flower buds ovate, ferruginous; sepals 5, hemisphere, concave, finely hairy on the outer surface, sparsely hairy on the inside, petals 7, finely hairy on the outer surface, with translucent margin, concave; style 5, 1/2 basally united; capsule 5 locular. Information on its phenology, distribution, ecology, and conservation status is also provided.
\end{abstract}

Keywords: Camellia sphamii; Langbiang Biosphere Reserve; Theaceae; Vietnam.

DOI: http://dx.doi.org/10.37569/DalatUniversity.12.3.947(2022)

Article type: (peer-reviewed) Full-lengthresearch article

Copyright (C) 2022 The author(s).

Licensing: This article is licensed under a CC BY-NC 4.0 


\section{INTRODUCTION}

Camellia L., the largest genus in the family Theaceae, is distributed throughout eastern and southeastern Asia, ranging from northeastern India in the west to Japan and the Philippines in the east and to Indonesia in the south (Souladeth et al., 2019). This genus has as general features opening fruits and seeds without wings. The flowers are bisexual and radially symmetric. The stamens are arranged in a ring and are often plentiful.The stamens are separated, or form a cup, and are united to the petal base. The anthers are dorsifixed.

Le et al. (2020) list 68 species and one variety of the genus Camellia L. The number of species has since increased to 95 species and there are now two varieties for this genus.

Recently, three new species of Camellia have been discovered and described from Lam Dong Province, Vietnam: Camellia flosculora (Le et al., 2021); Camellia proensis (Quach, Doudkin et al., 2021) and Camellia bidoupensis (Truong et al., 2020). This area has the potential to yield more new species.

During a botanical survey as part of the project "Conservation of endemic and endangered wild camellias outside the protected area of Lam Dong province, propagating and replanting into Bidoup Nui Ba National Park," we found a population of Camellia species that had not been previously identified. After sampling, analyzing in the laboratory, and comparing with morphologically similar Camellia species, we conclude that this species is new to science. This new species is named Camellia sphamii. In this article, the new species is described and classified according to its taxonomic position in the Sealy (1958) system. It is placed in the section Piquetia (Sealy, 1958).

\section{TAXONOMIC TREATMENT}

- $\quad$ Camellia sphamii Q. C. Truong \& V. S. Le, sp. nov. (Figures 1, 2)

\subsection{Type}

Vietnam, Lam Dong province, Don Duong district, D'ran town, Hamasin village, evergreen broadleaf forests, elevation 1,300-1,500 m, 28 Jan. 2021, Truong Quang Cuong, Le Van Son, Luong Van Dung, DL212801 (holotype DLU; isotype DLU, VTN).

\subsection{Description}

Shrub $2 \mathrm{~m}$ to $8 \mathrm{~m}$ high, evergreen, young branches purple, glabrous, shiny, flexuous; mature branches light brown, with longitudinally fissured bark; Leaves pendulous, glabrous, narrowly lanceolate, cordate at base, attenuate at apex, with shallowly toothed, undulate margin; young leaves purple, shiny; mature leaves coriaceous, shiny on both sides, adaxially light green, abaxially pale green, $40-55 \mathrm{~cm}$ 
long, $8.5-10 \mathrm{~cm}$ wide, midrib prominent on both sides; secondary venation brochidodromous, with 16-20 pairs of arched veins, adaxially slightly raised, abaxially prominent; tertiary venation adaxially distinct, abaxially indistinct; leaf petioles purple and straight when young, light green and falcate when mature, partially obstructed by leaf lamina on adaxial side, adaxially channeled, glabrous, $1.7-2 \mathrm{~cm}$ long, $2.5-3 \mathrm{~mm}$ wide, thick, angle of attachment variable, between $30^{\circ}$ and $90^{\circ}$. Flowers pedunculate, solitary, or 2(-3) clustered, borne on a short bracteate shoot in the axils of old leaves, nodding. Flower buds ovate, ferruginous; open flowers evenly circular, ca. $5 \mathrm{~cm}$ in diameter; pedicels stout, brownish-green or brown, shiny or crackled and corky, 1.2$2.2 \mathrm{~mm}$ long, $2 \mathrm{~mm}$ wide at the proximal end, glabrous. Bracteoles 2-3, broad, triangular, appressed to and scattered along the pedicel, hairy on the outer surface, ca. $2 \mathrm{~mm}$ long, $1 \mathrm{~mm}$ wide, distinctly differentiated from sepals, persistent. Sepals 5, ovate, 6-12 mm long, 10-19 mm wide, concave, coriaceous, finely hairy on the outer surface, with translucent margin, centrally green, marginally light yellow, persistent. Petals 6-7, finely hairy on the outer surface, with translucent margin, concave, 14-16 mm long, 16$18 \mathrm{~mm}$ wide; the outer whorl distinct with 3 petals, petals centrally green, distally light yellow; the middle and inner whorls of 2 petals each, petals yellow, with revolute margins. Androecium: filaments ca. 260, 5-6 whorls, light yellow, 13-18 mm long, basally united to each other for $3 \mathrm{~mm}$, inner filaments basally sparsely hairy, the outer filaments glabrous, basally united to the petals for 3-5 mm, anthers yellow, $2 \mathrm{~mm}$ long, $1 \mathrm{~mm}$ wide, with two longitudinal striations, dorsifixed. Gynoecium 4-5 locular, 2 ovules per locule, ovary superior, ovoidal, ca. $5 \mathrm{~mm}$ long, 3-4 mm in diameter, tomentose; styles 4-5, free, 9-10 mm long, basally densely hairy. Mature fruits capsular, corky, $5.5-6.5 \mathrm{~cm}$ in diameter, $3.5-4 \mathrm{~cm}$ deep, with persistent sepals, dehiscing distally into 4-5 parts, pubescent; columella stout, 2-2.3 cm long; pericarp 7$8 \mathrm{~mm}$ thick. Seeds semi-globose, $1.2-1.6 \mathrm{~cm}$ thick, $1.9-2.3 \mathrm{~cm}$ long, dark brownishpurple, glabrous.

\subsection{Phenology}

C. sphamii flowers from December to February of the following year and fruits from July to October.

\subsection{Distribution and ecology}

C. sphamii is recorded in only a single population in an evergreen broadleaf forest near the border of Lam Dong and Ninh Thuan provinces in Hamasin village, D'ran town, Don Duong district, Lam Dong province, Vietnam.

\subsection{Conservation status}

C. sphamii has only been recorded as a single population with fewer than 200 mature individuals in ca. 2 ha. In this area, there are many illegal logging operations and encroachments on forest land for agricultural activities. Therefore, the species can be assessed as critically endangered (CR) according to the IUCN categories and criteria (IUCN, 2019). 


\subsection{Etymology}

The specific epithet of this species honors Dr. S. Pham, Vice Chairman of Lam Dong Province People's Committee, Head of Langbiang Biosphere Reserve Management Board, and the founder of Langbiang Biosphere Reserve. Dr. S. Pham has been highly active in conservation activities in this area.

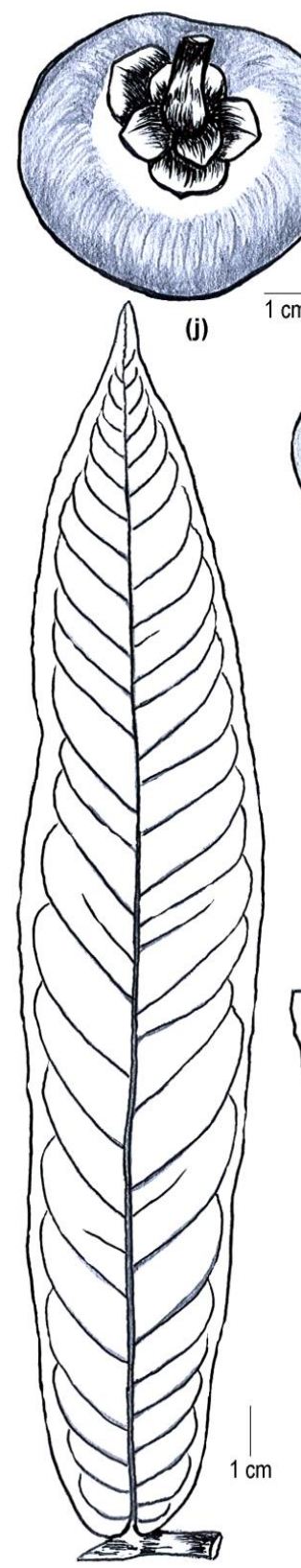

(a)
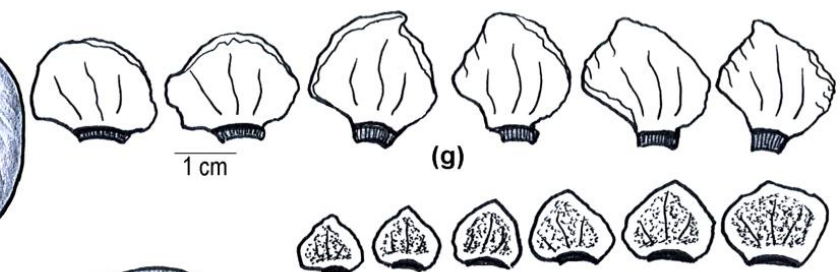

(g)

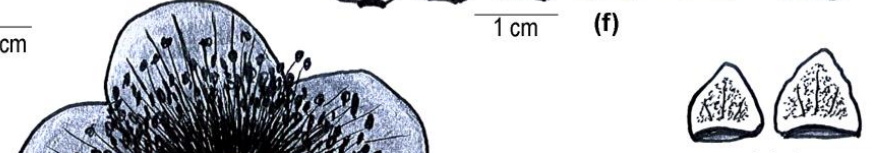

(e) $\overline{0.5 \mathrm{~cm}}$

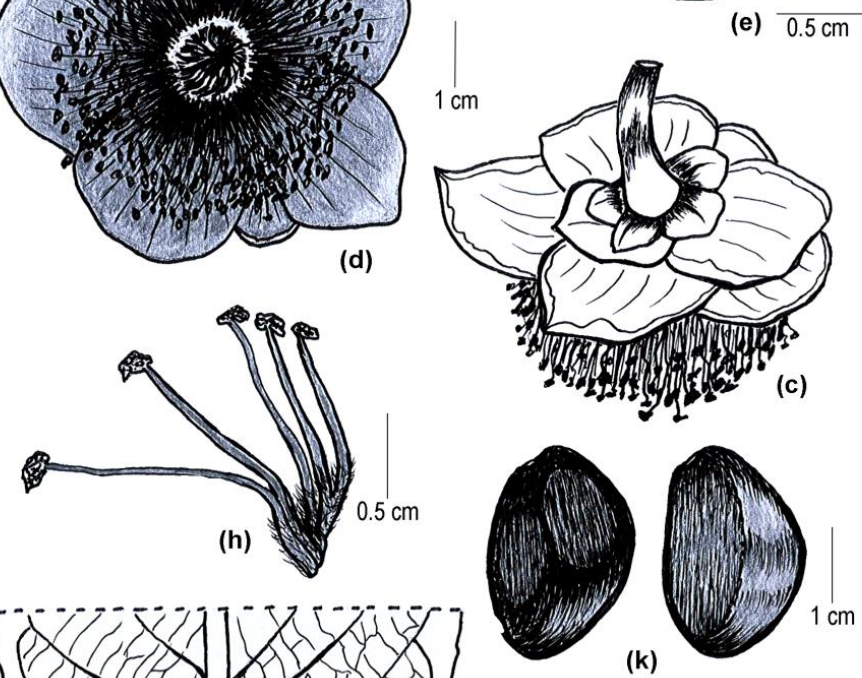

(k)

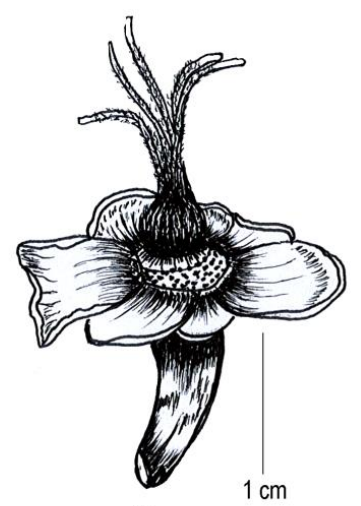

(i)

(b)

Figure 1. Camellia sphamii

Note: (a) Leaf; (b) Venation of leaf (abaxial surface); (c), (d) Flower; (e) Bracteoles; (f) Sepals; (g) Petals; (h) Filaments; (i) Sepals and gynoecium; (j) Fruit; (k) Seeds.

Source: Drawing by Luong Van Dung. 


\subsection{Note}

C. sphamii has as characteristics very big leaves, $40-55 \mathrm{~cm}$ long, $8.5-10 \mathrm{~cm}$ wide; flowers 1-2(3) on a short bracteate shoot in axils of old leaves; flowers pedicellate, nodding; bracteoles 2-3, persistent; sepals 5, persistent; petals 6-7, inter petals united with outermost filaments; gynoecium superior, ovary 4-5 locular, tomentose; styles 4-5, free. The new species has many characteristics of section Piquetia (Pierre) Sealy such as flowers borne on a short shoot in the axils of the leaves, usually 3-5 flowers on a shoot but sometimes 1 only, flowers pedicellate, nodding, pedicel very stout, thickened upwards; bracteoles $2-3$, persistent; sepals 5 , persistent; petals 8 or more; stamen free above the union with the petals, puberulous inside; gynoecium densely hairy; styles 5 or 6 (Pierre, 1887; Sealy, 1958). Therefore,Camellia sphamii is classified into the section Piquetia. Prior to this article, the Camellia sect. Piquetia (Sealy, 1958) in Vietnam included a total of 9 species, namely C. dalatensis, C. dongnaiensis, C. honbaensis, C.langbianensis, C. longii, C. piquetiana, C. proensis C. sonthaiensis, and C. vidalii (Luu et al., 2018; Orel, 2006; Orel et al., 2014; Pierre, 1887; Quach, Luong et al., 2021; Quach, Doudkin et al., 2021; Sealy, 1958; Tran \& Luong, 2012). The new species is easily distinguishable from C. honbaensis, C.piquetiana, and $C$. longii by the yellow flowers; from $C$. dalatensis by the glabrous twigs and leaves; from $C$. dongnaiensis and C.sonthaiensis by narrowly lanceolate leaves, cordate at the base, and pericarp $0.7-0.8 \mathrm{~cm}$ thick. $C$. sphamii is similar to $C$. proensis (Quach, Luong et al., 2021) but differs from it in several morphological features: mature leaves cordate at base, young leaves purple; pericarp 7-8 $\mathrm{mm}$ thick and dense hair on the outer surface, flower buds ovate, ferruginous; sepals 5, hemisphere, concave, finely hairy on the outer surface, sparsely hairy on the inside, petals 6-7, finely hairy on the outer surface, with translucent margin, concave; style $5,1 / 2$ basally united; capsule 5 locular. The species of Camellia sect. Piquetia can be distinguished using the following key:

1a. Flowers red

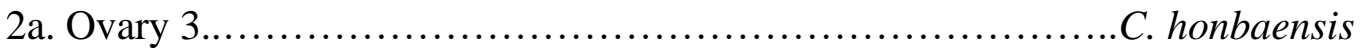

2b. Ovary 5

3a. Petal 5-6, campanulate........................................... longii

3b. Petal 8 or more, rotate..................................... piquetiana

1b. Flowers orange or yellow

2a. Flowers orange

3a. Young branches and leaves glabrous......................... dongnaiensis

3b. Young branches and leaves hairy .............................. langbianensis

$2 b$. Flowers yellow 
4a. Young branches and leaves hairy C. dalatensis

4b. Young branches and leaves glabrous

5a. Leaves cordate at base. C. sphamii

$5 b$. Leaves rounded or acute at base

6a. Leaves narrowly lanceolate; ovary (3)-4; mature fruit $1.5-2 \mathrm{~cm}$ high, 3-3.5 cm wide, C. sonthaiensis

6b. Leaves oblong-elliptic; ovary 4-5 locular; mature fruit 4-5.5 cm high, $8.5-$ $10 \mathrm{~cm}$ wide.

C. proensis

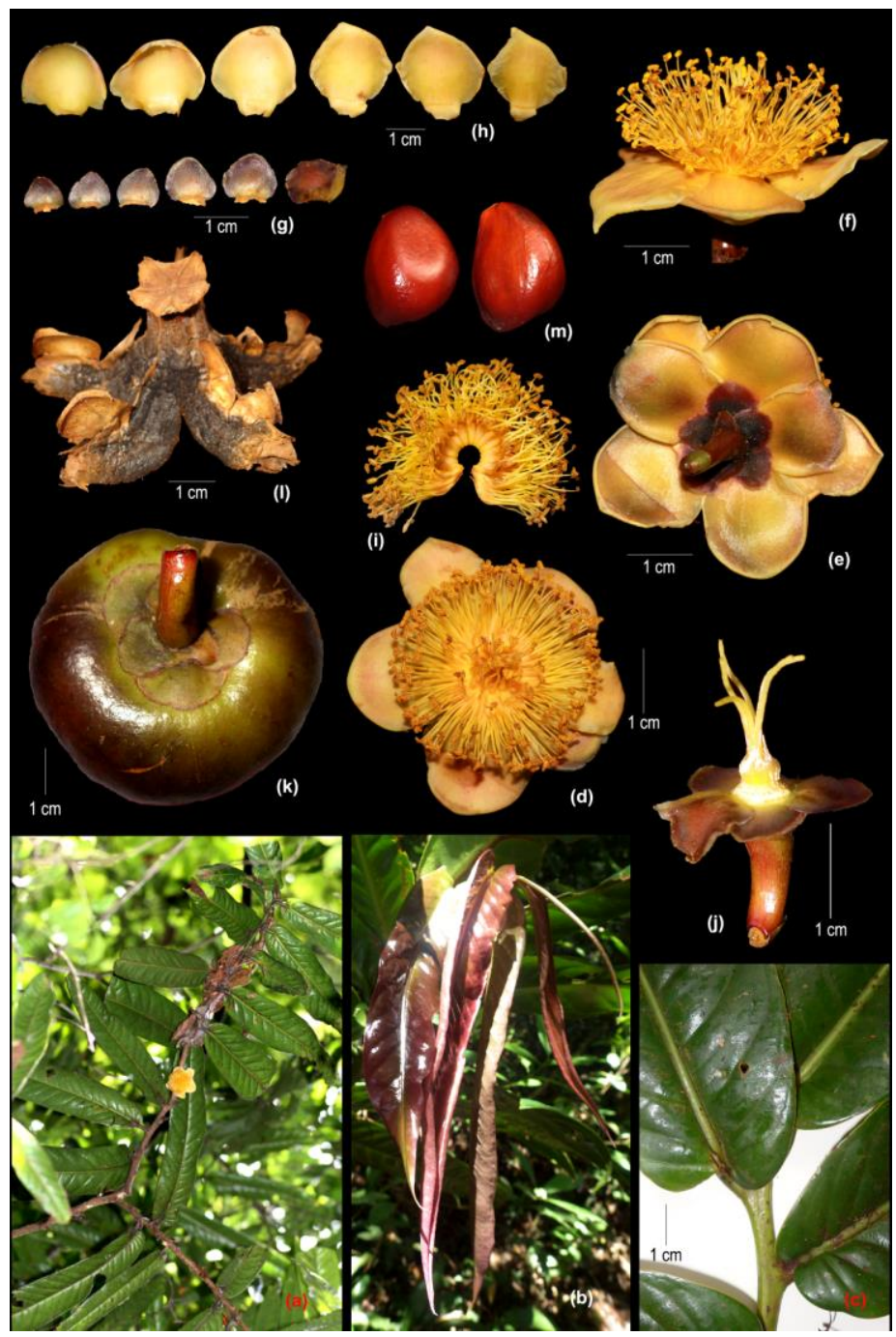

Figure 2. Camellia sphamii

Note: (a) Adult branch showing flower; (b) Twigs; (c) Young branch; (d) Flower (top view);

(e) Flower (rear view); (f) Flower (side view); (g) Sepals; (h) Petals; (i) Androecium;

(j) Sepals and gynoecium; (k) Fruit; (l) Dehisced capsule; (m) Seeds.

Source: Photos by Truong Quang Cuong and colored plate by Luong Van Dung. 


\section{ACKNOWLEDGMENTS}

This study was partially supported by the Fondation Franklinia, Switzerland. In the framework of the project: "Conservation of endemic and endangered wild camellias outside the protected area of Lam Dong province, propagating and replanting into Bidoup Nui Ba National Park".

\section{REFERENCES}

IUCN. (2019). Guidelines for using the IUCN red list categories and criteria. http://www.iucnredlist.org/documents/RedListGuidelines.pdf.

Le, N. H. N., Luong, V. D., Nguyen, V. C., Pham, T. T. D., Luu, T. T., \& Pham, V. T. (2020). An updated checklist of Theaceae and a new species of Polyspora from Vietnam. Taiwania, 65(2), 216-227. https://doi.org/10.6165/tai.2020.65.216

Le, V. S., Curry, A. S., Truong, Q. C., Luong, V. D., \& Nguyen, T. L. (2021). Camellia flosculora: a new species of Camellia section Thea series Sinenses (Theaceae) from Vietnam. Brittonia, 73, 220-228. https://doi.org/10.1007/s12228-020-09646-5

Luu, H. T., Tran, G., Nguyen, Q. D., \& Nguyen, H. C. (2018). A new species of the family Theaceae from central Vietnam. Academia Journal of Biology, 40(4), 2328. https://doi.org/10.15625/2615-9023/v40n4.12919

Orel, G. (2006). A new species of Camellia section Piquetia (Theaceae) from Vietnam. Novon: A Journal for Botanical Nomenclature, 16(2), 244-247. https://doi.org/10.3417/1055-3177(2006)16[244:ANSOCS]2.0.CO;2

Orel, G., Wilson, P. G., Curry, A., \& Luu, H. T. (2014). Four new species and two new sections of Camellia (Theaceae) from Vietnam. Novon: A Journal for Botanical Nomenclature, 23(3), 307-318. https://doi.org/10.3417/2012076

Pierre, L. (1887). Flore Forestière de la Cochinchine. Octave Doin.

Quach, V. H., Doudkin, R. V., Truong, Q. C., Le, V. S., Luong, V. D., Kim, S., \& Yang, S. (2021). Rediscovery of Camellia langbianensis (Theaceae) in Vietnam. Phytotaxa, 480(1), 85-90. https://doi.org/10.11646/phytotaxa.480.1.8

Quach, V. H., Luong, V. D., Doudkin, R. V., Averyanov, L. V., Bui, B. T., Nguyen, T. L.,\& Luu, H. T. (2021). Camellia proensis (Theaceae, sect. Piquetia), a new species from Southern Vietnam. Phytotaxa, 479(1), 137-141. https://doi.org/ 10.11646/phytotaxa.479.1.12

Sealy, J. R. (1958). A revision of the genus Camellia. Royal Horticultural Society.

Souladeth, P., Tagane, S., \& Yahara, T. (2019). Flora of Nam Kading National Protected Area V: Two new species of Camellia (Theaceae), C. namkadingensis and C. rosacea. Thai Forest Bulletin (Botany), 47(1), 82-90. https://doi.org/ 10.20531/tfb.2019.47.1.12 
Tran, N., \& Luong, V. D. (2012). Camellia dalatensis: A new species and precious gene should be conserved. VNU Journal of Science: Natural Science and Technology 28(2S), 34-36.

Truong, Q. C., Luong, V. D., Le, V. S., Tran, N., \& Curry, A. (2020). Camellia bidoupensis - A new species of Camellia section Theopsis (Theaceae) from Bidoup Nui Ba National Park in Vietnam. International Camellia Journal, 52, 125-128. 